\title{
ANALYSIS OF INTERNAL CONTROL OF FIXED ASSETS IN PT. LUMBUNG BERKAT INDONESIA
}

\author{
Jesella Lourina Makaluas ${ }^{1}$, Winston Pontoh ${ }^{2}$ \\ ${ }^{1,2}$ Pendidikan Profesi Akuntansi, Fakultas Ekonomi dan Bisnis, Universitas Sam Ratulangi, Jl. Kampus Bahu, \\ Manado, 95115, Indonesia
}

Corresponding e-mail: orinmakaluas@gmail.com

\begin{abstract}
The presence of an internal control system of fixed assets that will assist management in supervising, monitors costs incurred when fixed assets are acquired until property, plant, and equipment are released. Adding or extending the useful life of fixed assets and assisting in increasing the operational contribution and productive capacity of the company's fixed assets maintain security, check the accuracy and correctness of data from the company's fixed assets. This study aims to determine the implementation of the structure of Internal Controls of Fixed Assets conducted in PT Lumbung Berkat Indonesia which is a type of construction company. The analysis method used is descriptive method. Data type is qualitative data with secondary data source. The result of the research shows that internal control in PT Lumbung Berkat Indonesia has not been effective yet. This is seen from the lack of separation of duties and responsibilities between the finance and accounting departments, the absence of an audit committee, never conducting tests and measurements on fixed assets. Any decision relating to fixed assets shall first be authorized by the President Director, but the company never conducts physical property checks and matching with fixed assets records. There is also no expenditure on capital and revenues. Depreciation method used is straight line depreciation and implemented continuously every year. However, the list of fixed assets of the company has not been up to date since the company only attaches fixed assets in the form of buildings and vehicles in the project (excluding vehicles and inventory in the office).
\end{abstract}

Keywords: Internal Control, Fixed Assets.

\section{INTRODUCTION}

The development of the business world in Indonesia from year to year increasing rapidly, which is supported by the progress of science, technology, and globalization, which impact on the emergence of intense competition among companies. This condition of course requires the company to maintain and expand its business by focusing more on utilizing all resources owned by company to be used effectively and efficiently.

Assets that are influential in the smooth operation of the company's operations are fixed assets, which are capital factors that have large values and important positions in the company, because they require a large amount of funds and embedded in a long time in achieving the goal. Therefore, good planning and supervision of management are required.

The company's fixed asset may be a significant part of the total assets. To maximize the role, the fixed assets should receive adequate attention from the management and appropriate policies in the management of fixed assets, such as determining how the acquisition of fixed assets, depreciation method, and expenses are incurred when the assets are used. The cost of a fixed asset includes the total amount incurred to acquire the asset. Fixed assets will be reported on the balance sheet, not only at their purchase price, but also all costs incurred until the fixed assets are ready for their intended use. 
Therefore, the company needs an internal control system. The Internal control over fixed assets is a system, method, procedure, plan, and policy that uses all company resources aiming to assist management in supervising, controlling costs incurred to acquire fixed assets, adding or extending the useful life of fixed assets, and increasing contributions operational and productive capacity of fixed assets to safeguard the security of the company's property, check the accuracy and correctness of accounting data, and even help encourage compliance with the stipulated policy of the former. PT Lumbung Berkat Indonesia as a company entity engaged in construction, of course, has various types of fixed assets. With good internal control, it can provide financial information reports of the companies that reflect the true value of a fixed asset.

\section{LITERATURE REVIEWS}

\section{Definition of Internal Control}

According to Hery (2014: 188), internal control is a set of policies and procedures to protect the company's assets of misuse, ensure accurate accounting information of the company and all legal and regulatory provisions management that have been complied with or executed accordingly by all employees of the company.

The Internal Control Components Committee of Supporting Organization of the Tredway Commission (COSO)

According to COSO in Karyono's book (2013: 3), internal control consists of five elements, namely:

1. Control Environment

2. Risk Assessment

3. Control Activities

4. Information and Communication

5. Monitoring

\section{Definition of Fixed Assets}

Surya (2012: 149) discloses that fixed assets of tangible assets owned by a company for use in the production or supply of goods or services, for lease or administrative purposes; and expectations can be used for more than one period.

In PSAK No. 16 of 2015, what is meant by fixed assets are tangible assets which:

a. Owned for the use in the production or supply of goods or services, to be rent to other parties, or for administrative purposes; and

b. Expected to be used for more than one period

\section{How to Acquire Fixed Assets}

1. Cash Purchases

2. Purchase on credit

3. Exchange with existing nonmonetary assets

4. Issuing shares (capital securities) or bonds (securities of money)

5. Own Construction

6. Received from Donations

\section{Capital Expenditure and Expenditure Revenue}

According to Hery (2014: 107), capital expenditure is the cost incurred in acquiring fixed assets, improving operational efficiency and productive capacity of fixed assets, and extending the useful life of fixed assets. These costs are usually issued in sufficient large quantities, but not often. Whereas revenue expenditure is the cost that will only give benefit in the current period, so this expense will not be capitalized as a fixed asset in the balance sheet, but will be directly charged as an expense in the statement of income on the current period where the cost is incurred (issued). 


\section{Termination of Fixed Assets}

According to PSAK No. 16 of 2015, the carrying amount of property and equipment is derecognized:

a. At the time of disposal; or

b. When there is no longer expected future economic benefits from its use or disposal.

\section{Internal Control over Fixed Assets}

According to Wulandari (2013), Internal controls related to fixed asset acquisition transactions are policies and procedures that are defined for fixed assets. The project of acquisition of property, plant, and equipment shall be approved and monitored for conformity with the budget. The amount of costs that should have been issued shall be monitored accordingly.

According to Hery (2014: 191), the handling of fixed assets in internal controls is runnning with the aim of ensuring that the company's fixed assets are used properly and only to support the day-to-day operations of the company.

\section{Previous Research}

1. Muhammad Syahmi Santosa (2014) entitled "The Role of Fixed Assets Control on Fixed Assets Management of Regional Water Company (PDAM) Pekalongan" .The author's purpose was to know whether or not the weakness of Internal Control System exist in PDAM Pekalongan City in detecting damage of fixed assets as well as the economic age of fixed assets. The research method used was descriptive method. The result of this research was that the company of Drinking Water Region (PDAM) Pekalongan has internal control structure over the effectiveness of fixed asset. This is seen in the implementation of using fixed assets in accordance with procedures applicable in PDAM Pekalongan. There were similarities and differences with research conducted by the author. Similarly, previous research was conducted on the same factors that are associated with fixed assets. The difference was in the object of research that more emphasis on the corporate control environment associated with the organizational structure at PT Lumbung Berkat Indonesia.

2. Erwin Budiman (2016) entitled "Analysis of Internal Control of Fixed Assets at PT. Hasjrat Multifinance Manado Branch". The author's goal was to find out the implementation of internal control structure of fixed assets conducted at PT. Hasjrat Multifinance. The research method used was descriptive. The result of the research was that the internal control applied to PT Hasjrat Multifinance has not effectively run well. The company did not carry out tests on fixed asset. The fixed assets were not numbered and conducted in physical inspection. There were similarities and differences with research conducted by the author. Similarly, previous research was conductedon the same factors that are associated with fixed assets. The difference is in the object of research

\section{RESEARCH METHOD}

\section{Types and Data Source}

The type of data used by the author in the preparation of this thesis is qualitative, with the object of research is in PT Lumbung Berkat Indonesia. Source of data used by the author in the preparation of this thesis is secondary, in the form of fixed asset list, a brief history of the company and corporate organizational structures, and information on depreciation of fixed assets.

\section{Data Collection Techniques in this study are as follows;}

\section{Field Research}

This research used a direct survey to the of PT.Lumbung Berkat Indonesia.

\section{Library Research}


This research obtaining theoretical data through reviewing theories about internal control of fixed assets in books and articles on fixed assets.

\section{Electronic Media}

This research obtaining from web browsing in the form of journals as learning from several sources relating to internal control of fixed assets.

4. Interview (Interview)

The researcher conducts interviews with company managers and related employees to get an explanation of how the acquisition of fixed assets, methods of depreciation of fixed assets and how they are recorded in the financial statements.

\section{Data Analysis Method}

The method used to analyze the data is descriptive to describe the systematic and factual analysis of internal control asset in PT Lumbung Berkat Indonesia.

\section{Data Analysis Technique}

Is the application of the system by using 5 (five) internal control elements related to the problem under study which are;

1. Control Environment

2. Risk Assessment

3. Control Activities

4. Information and Communication

5. Supervision

\section{RESULTS AND DISCUSSIONS}

\section{Company's General Description}

PT. Lumbung Berkat Indonesia which based in Manado was established based on Deed No. 28. On January 29, 2010 from Notary: Ivonne Yuliet Pesik, SH, and has been approved by the Ministry of Justice and Human Rights of the Republic of Indonesia Number: AHU- 17904.AH.01.01 Year 2010, dated 09 April 2010. In accordance with the latest deed of establishment and amendment, the purpose of this company is to establish and run a business in areas of: Trade Services, Building Construction and Civil Building, in accordance with the Company's Business License and Company's Certificate of Registration, with working area for all of North Sulawesi and its surroundings. The organizational structure adopted by PT Lumbung Berkat Indonesia only has one office located in Manado. The following are the divisions of authority and responsibility of each part in PT Lumbung Berkat Indonesia.

\section{a. President Director}

1. Responsible for company policies concerned decisions taken

2. Responsible for employee recruitment

3. Responsible for procurement and handling company needs

4. Fostering good relationships with the leasing

5. Fostering good relationship with customer

\section{b. Commissioner}

1. Supervising the company's activities

\section{c. Director of Finance}

1. Organising and managing any existing expenditures

2. Noting each company's expenses

3. Checking the company's financial statements

4. Responsible for company report 
d. Director of Operations

1. Responsible in the field

2. Ensuring the project period

3. Implementing the right strategy

4. Budgeting project inventory needs

5. Supervising the workforce and be responsible for fixed assets in the project

e. Finance and Accounting Staff

1 . Recording any company expenses

2. Data input of every data that goes into the application

3. Preparing Financial Statement if requested by the President Director

4. Managing corporate administration such as office inventory

f. Taxation \& HRD

1. Organising and reporting the company's taxes every month on time, including:

- Organising and reporting company's taxes.

- Setting and reporting employee's income taxes.

2. responsible as an intermediary of application files to be given to the President Director

3. Creating a list of depreciation of fixed assets.

\section{Research Result}

\section{Company Activity}

a) Recognition of Acquisition Cost of Property

Each fixed asset of PT Lumbung Berkat Indonesia is obtained through cash purchases and leasing.

\section{b) Measurement of Fixed Asset Value}

PT Lumbung Berkat Indonesia measures its property, plant, and equipment at the cost of fixed assets when is incurred (historical cost method), ie fixed assets are measured at the cost of fixed assets and reduced by accumulated depreciation

c) Spending after Acquisition of Fixed Assets

PT Lumbung Berkat Indonesia recognizes maintenance and repair expenses, because these expenditures are frequent in each period

d) Depreciation of Fixed Assets

In accordance with the Company's policy, the method of depreciation of fixed assets of PT Lumbung Berkat Indonesia uses the straight line method.

e) Termination and Disposal of Fixed Assets

Each fixed asset of PT Lumbung Berkat Indonesia never stops the fixed assets yet.

\section{Structure of Internal Control of Fixed Assets in PT. Lumbung Berkat Indonesia Control Environment}

The Company does not have a corporate philosophy. Job descriptions are not in detail related to fixed assets policy. Provision of tasks is not in accordance with the work part. There is no internal audit in the company, but all are only controlled directly by the president. In managing human resources, PT Lumbung Berkat Indonesia set a training program of one month to complete basic skills that are useful in carrying out tasks and does not have an audit committee.

\section{Risk Assessment}

Risk assessments conducted by PT Lumbung Berkat Indonesia, are as follows;

a) There has never been any test of the possibility of impairment when there are significant changes, either in the use of assets or changes in the business environment. 
b) Absence of separation of capital and revenue expenditure for fixed assets in accordance with PSAK No. 16.

\section{Control Activities}

Implementation of fixed asset controlling at PT Lumbung Berkat Indonesia, conducted based on the authorization from the leadership that is:

a) Fixed asset improvements authorized by Operations and Managing Director

b) Purchased fixed assets are authorized by the President Director then budgeting by the Finance Department.

c) For the disposal of fixed assets, the company does not perform it yet, because according to the management of the fixed asset company it always regenerate when its value is almost exhausted. Even if the value is almost gone, the value is not up to 0 (zero). So, until now the company's fixed assets have never been removed / deleted / sold. This section is authorized directly by the financial and accounting divisions and the President Director

d) The cash out proof is authorized by the Finance Department and President Director.

\section{Relevant Information Systems and Business Processes to Financial and Communication Reporting}

Data Registration conducted by PT Lumbung Berkat Indonesia for fixed asset depreciation method using straight-line depreciation starting from 2011 to 2016

\begin{tabular}{|c|c|c|c|c|c|c|}
\hline No & Device Name & $\begin{array}{l}\text { Acquisition } \\
\text { Year }\end{array}$ & Type/Brand & $\begin{array}{c}\text { Acquisiton Value } \\
\text { (Rp) }\end{array}$ & $\begin{array}{c}\text { Useful Life } \\
\text { (Month) }\end{array}$ & Note \\
\hline 1 & Stone Crusher & 29.04 .2011 & Zenit & $1,567,933,500$ & 96 & New \\
\hline \multirow[t]{2}{*}{2} & $\begin{array}{l}\text { Aspalt Mixing Plant } \\
(\text { AMP) }\end{array}$ & \multirow[t]{2}{*}{ 19.08.2011 } & \multirow[t]{2}{*}{ RB China/LBJ1000/TYPE1000 } & \multirow[t]{2}{*}{$2,600,000,000$} & \multirow[t]{2}{*}{96} & \multirow[t]{2}{*}{ New } \\
\hline & Dan Aspalt Sprayer & & & & & \\
\hline 3 & Aspalt Finisher & 20.09 .2011 & NFB6W1 & $640,000,000$ & 96 & New \\
\hline 4 & Dynapac Roller & 20.09.2011 & Dynapac/CC222 & $540,000,000$ & 96 & $\begin{array}{c}\text { Used } \\
(2008)\end{array}$ \\
\hline 5 & Tire Road Roller & 11.10 .2011 & Sakai/TS600C & $358,000,000$ & 96 & New \\
\hline 6 & $\begin{array}{l}\text { Vibratory Pneum } \\
\text { Compactor }\end{array}$ & 29.04.2011 & Cat/Cs-533E & $789,835,200$ & 96 & New \\
\hline 7 & Excavator & 28.02 .2011 & Cat $320 \mathrm{D}$ & $1,104,829,000$ & 96 & New \\
\hline 8 & Excavator & 31.03 .2011 & Cat $320 \mathrm{D}$ & $1,104,829,000$ & 96 & New \\
\hline 9 & Motor Grader & 28.04 .2011 & Cat-120K SZ & $1,438,628,400$ & 96 & New \\
\hline 10 & Wheel Loader & 05.04 .2011 & Komatsu/WA200-5 & $740,000,000$ & 96 & $\begin{array}{l}\text { Used } \\
(2008)\end{array}$ \\
\hline 11 & Wheel Loader & 05.04 .2011 & Komatsu/WA300 & $875,000,000$ & 96 & $\begin{array}{l}\text { Used } \\
(2008)\end{array}$ \\
\hline 12 & Dump Truck & 25.05 .2011 & Izusu 71HDE2-1su NKR & $201,428,571$ & 96 & New \\
\hline 13 & Dump Truck & 25.05 .2011 & Izusu 71HDE2-1su NKR & $201,428,571$ & 96 & New \\
\hline 14 & Dump Truck & 25.05 .2011 & Izusu 71HDE2-1su NKR & $201,428,571$ & 96 & New \\
\hline 15 & Dump Truck & 25.05 .2011 & Izusu 71HDE2-1su NKR & $201,428,571$ & 96 & New \\
\hline 16 & Dump Truck & 25.05 .2011 & Izusu 71HDE2-1su NKR & $201,428,571$ & 96 & New \\
\hline 17 & Dump Truck & 25.05 .2011 & Izusu 71HDE2-1su NKR & $201,428,571$ & 96 & New \\
\hline 18 & Aspalt Finisher & 13.07 .2012 & NFB63CVKBZ-NFB6C & $620,000,000$ & 96 & \\
\hline 19 & Road Roller & 13.07 .2012 & Sakai/sw800 & $710,000,000$ & 96 & \\
\hline 20 & Alpalt Sprayer & 10.05 .2012 & ASP/electric Burner & $72,500,000$ & 96 & \\
\hline 21 & Truck Water Tanker & 21.05 .2012 & Izusu/Bison & $275,000,000$ & 96 & New \\
\hline 22 & Dump Truck & 31.07 .2012 & Izusu vz34p & $925,000,000$ & 96 & New \\
\hline 23 & Dump Truck & 31.07 .2012 & Izusu vz34p & $925,000,000$ & 96 & New \\
\hline 24 & Dump Truck & 31.07 .2012 & Izusu vz34p & $925,000,000$ & 96 & New \\
\hline 25 & Dump Truck & 31.07 .2012 & Izusu vz34p & $925,000,000$ & 96 & New \\
\hline 26 & Excavator Hitachi & 20.05 .2013 & EXC.HITACHI & $1,207,350,000$ & 96 & \\
\hline 27 & Motor Grader & 11.04 .2014 & Cat-120 K & $1,866,645,000$ & 96 & \\
\hline 28 & $\begin{array}{l}\text { Vibratory Pneum } \\
\text { Compactor }\end{array}$ & 11.04.2014 & Cat/Cs-533E & $908,433,900$ & 96 & \\
\hline 29 & Tire Roller & 23.06 .2014 & Sakai/TS205 & $879,120,000$ & 96 & \\
\hline 30 & Vibrating Roller & 02.04 .2014 & Sakai/CR271 & $248,270,000$ & 96 & \\
\hline 31 & Dump Truck & 20.05 .2015 & HINO/Dutro130HD6.8PS & $334,000,000$ & 96 & New \\
\hline 32 & Dump Truck & 20.05 .2015 & HINO/Dutro130HD6.8PS & $334,000,000$ & 96 & New \\
\hline 33 & Dump Truck & 20.05 .2015 & HINO/Dutro130HD6.8PS & $334,000,000$ & 96 & New \\
\hline 34 & Dump Truck & 20.05 .2015 & HINO/Dutro130HD6.8PS & $334,000,000$ & 96 & New \\
\hline
\end{tabular}




\begin{tabular}{|c|c|c|c|c|c|c|}
\hline No & Device Name & $\begin{array}{c}\text { Acquisition } \\
\text { Year }\end{array}$ & Type/Brand & $\begin{array}{c}\text { Acquisiton Value } \\
(\mathbf{R p})\end{array}$ & $\begin{array}{l}\text { Useful Life } \\
\text { (Month) }\end{array}$ & Note \\
\hline 35 & Dump Truck & 20.05 .2015 & HINO/Dutro130HD6.8PS & $334,000,000$ & 96 & New \\
\hline 36 & Truck Tronton & 20.05 .2015 & HINO/FM260JW & $875,000,000$ & 96 & New \\
\hline 37 & Avanza DB.1416 EF & 23.06 .2015 & Toyota/Mobil Penumpang & $227,205,000$ & 96 & New \\
\hline 38 & Dump Truck & 24.09.2016 & $\begin{array}{c}\text { HINO DUTRO } 130 \\
\text { HDXPOWER }\end{array}$ & $277,272,727$ & 96 & New \\
\hline 39 & Dump Truck & 24.09.2016 & $\begin{array}{l}\text { HINO DUTRO } 130 \\
\text { HDXPOWER }\end{array}$ & $277,272,727$ & 96 & New \\
\hline 40 & Dump Truck & 24.09.2016 & $\begin{array}{c}\text { HINO DUTRO } 130 \\
\text { HDXPOWER }\end{array}$ & $277,272,727$ & 96 & New \\
\hline 41 & Dump Truck & 24.09 .2016 & $\begin{array}{l}\text { HINO DUTRO } 130 \\
\text { HDXPOWER }\end{array}$ & $277,272,727$ & 96 & New \\
\hline 42 & Dump Truck & 24.09 .2016 & $\begin{array}{c}\text { HINO DUTRO } 130 \\
\text { HDXPOWER }\end{array}$ & $277,272,727$ & 96 & New \\
\hline 43 & Mobil Avanza & 15.11 .2013 & Toyota/Mobil Penumpang & $100,000,000$ & 96 & Used \\
\hline 44 & Mobil Avanza & 15.08 .2013 & Toyota/Mobil Penumpang & $80,000,000$ & 96 & Used \\
\hline 45 & Mobil Avanza & 20.09 .2015 & Toyota/Mobil Penumpang & $140,000,000$ & 96 & Used \\
\hline 46 & Mobil Pick Up & 27.09 .2013 & Toyota Hilux & $120,000,000$ & 96 & Used \\
\hline 47 & Mobil Pick Up & 16.07 .2015 & Toyota Hilux & $130,000,000$ & 96 & Used \\
\hline 48 & Mobil Pick Up & 28.04 .2014 & Toyota Hilux & $110,000,000$ & 96 & Used \\
\hline 49 & Alat ukur LDP D810 & 25.02 .2016 & & $17,180,000$ & 96 & New \\
\hline 50 & $\begin{array}{c}\text { Alat Blending } \\
\text { Equipment }\end{array}$ & 03.04 .2016 & & $300,000,000$ & 96 & New \\
\hline 51 & Alat Lab & 29.04 .2016 & & $94,700,000$ & 96 & New \\
\hline 52 & Genzet 1 unit & 30.04 .2016 & & $227,000,000$ & 96 & New \\
\hline 53 & Alat Sandcone & 15.06 .2016 & & $55,000,000$ & 96 & New \\
\hline 54 & Mobil Innova & 09.09 .2016 & & $348,390,491$ & 96 & New \\
\hline 55 & Gedung Kantor & 16.08 .2016 & & $1,450,000,000$ & 240 & \\
\hline
\end{tabular}

\section{Source: Processed Data in 2017}

\section{Monitoring Control}

Monitoring control conducted by PT Lumbung Berkat Indonesia namely:

a. The Company has never conducted a physical inspection of fixed assets (once a year).

b. Never remove a fixed asset whose book value that is exhausted and which cannot be used for the company's operations, but still in the fixed asset control card.

\section{Discussion}

\section{Analysis and Evaluation of Organizational Structure}

Implementation of the internal control environment of fixed assets in PT Lumbung Berkat Indonesia, based on the organizational structure needs to be done a separation of duties and responsibilities between the finance and bookkeeping. This is because based on to accounting standards that applies the financial and bookkeeping, it must be separated, because it is more controlled and reduce misdirected actions.

\section{Analysis and Evaluation of Internal Control of Fixed Assets}

\section{Control Environment}

\begin{tabular}{|c|c|c|}
\hline Theory & $\begin{array}{l}\text { Application in PT Lumbung } \\
\text { Berkat Indonesia }\end{array}$ & Analysis Result \\
\hline $\begin{array}{l}\text { Management } \\
\text { Philosophy and } \\
\text { Operating Style }\end{array}$ & Has no philosophy & $\begin{array}{l}\text { Ineffective, because it has no philosophy that will become } \\
\text { the characteristics and guidelines of the company. }\end{array}$ \\
\hline $\begin{array}{l}\text { Organizational } \\
\text { Structure }\end{array}$ & $\begin{array}{l}\text { Job description is not in detail } \\
\text { related to fixed assets policy. }\end{array}$ & Ineffective, resulting in a lack of work control. \\
\hline Audit Committee & $\begin{array}{l}\text { Assignment that does not fit the } \\
\text { section }\end{array}$ & $\begin{array}{l}\text { Ineffective, resulting in inequalities in outline and out-of- } \\
\text { line procedures, does not work as part of its function. }\end{array}$ \\
\hline
\end{tabular}


Internal Audit Does not have an audit committee
Function
Ineffective, which will lead to a lack of supervision of the company's activity process, so that it will lead to misappropriation and recording errors that affect the presentation of financial statement information

\begin{tabular}{|c|c|c|}
\hline $\begin{array}{l}\text { Employee Practices } \\
\text { and Policies }\end{array}$ & $\begin{array}{l}\text { There is no Internal audit, only the } \\
\text { Managing Director alone handles } \\
\text { and oversees the company's } \\
\text { activities }\end{array}$ & $\begin{array}{l}\text { Ineffective, because it cannot audit the concerned lack of } \\
\text { time to supervise every part because of the business of the } \\
\text { President Director }\end{array}$ \\
\hline $\begin{array}{l}\text { Employee Practices } \\
\text { and Policies }\end{array}$ & $\begin{array}{l}\text { Does not provide adequate training } \\
\text { time (only } 1 \text { month), and does not } \\
\text { have a specific training program for } \\
\text { employees. } \\
\text { No physical inspection of fixed } \\
\text { assets (once a year) }\end{array}$ & $\begin{array}{l}\text { Not effective, because within a company, goals will be } \\
\text { achieved if employees work efficiently supported with } \\
\text { knowledge and skills that have been trained. } \\
\text { Ineffective, as there may be differences between reports } \\
\text { with physical presence in the field due to fraud, } \\
\text { misappropriation, and embezzlement in field projects. }\end{array}$ \\
\hline
\end{tabular}

Source: Processed Data in 2017

\section{Risk Assesement}

\begin{tabular}{llll}
\hline \multicolumn{1}{c}{ Theory } & \multicolumn{1}{c}{$\begin{array}{c}\text { Application in PT Lumbung Berkat } \\
\text { Indonesia }\end{array}$} & Analysis Result \\
\hline $\begin{array}{l}\text { Accounting Policies (impairment } \\
\text { property, plant, and equipment) }\end{array}$ & $\begin{array}{l}\text { The Company did not conduct a test in Not effective, because in the financial } \\
\text { accordance with PSAK no } 48 \\
\text { "impairment of property and } \\
\text { equipment" }\end{array}$ & $\begin{array}{l}\text { intements it may not necessarily reflect the } \\
\text { actual book value. }\end{array}$ \\
\hline Changes in accounting standards & $\begin{array}{l}\text { The expenditure on fixed assets of the } \\
\text { company is directly charged only to the }\end{array}$ & $\begin{array}{l}\text { Not effective, because there could be } \\
\text { aspenditure of fixed assets that can be used } \\
\text { expenditure (revenue expenditure) }\end{array}$ \\
\hline
\end{tabular}

Source: Processed Data in 2017

Control Activity

\begin{tabular}{|c|c|c|}
\hline Theory & $\begin{array}{l}\text { Application in PT Lumbung Berkat } \\
\text { Indonesia }\end{array}$ & Analysis Result \\
\hline $\begin{array}{llll}\text { Authorize } & \text { Transactions } & \text { on } & \text { Fixed } \\
\text { Assets } & & & \\
\end{array}$ & $\begin{array}{l}\text { Any company transactions related to } \\
\text { fixed assets are directly authorized by } \\
\text { the President Director. }\end{array}$ & $\begin{array}{l}\text { This is good, in order to prevent abuse of } \\
\text { authority. }\end{array}$ \\
\hline Supervision of Fixed Assets & $\begin{array}{l}\text { Lack of adequate control of the finance } \\
\text { and bookkeeping }\end{array}$ & Effective, so it can detect loss of fixed assets. \\
\hline Physical Control of Fixed Assets & $\begin{array}{l}\text { There has never been a physical fixed } \\
\text { asset matching with a fixed asset } \\
\text { record }\end{array}$ & $\begin{array}{l}\text { Ineffective, because in order to prevent } \\
\text { embezzlement, fraud or misappropriation of } \\
\text { company fixed assets, physical matching } \\
\text { must be made with a fixed asset record. }\end{array}$ \\
\hline $\begin{array}{l}\text { Physical Control Over Fixed Asset } \\
\text { Records }\end{array}$ & $\begin{array}{l}\text { Fixed assets for purchasing must first } \\
\text { be approved by the President Director } \\
\text { to approve the letter of request for such } \\
\text { funds }\end{array}$ & $\begin{array}{l}\text { Effective, because it has been through } \\
\text { approval. }\end{array}$ \\
\hline Disposal of Fixed Assets & $\begin{array}{l}\text { The Company did not release any fixed } \\
\text { assets }\end{array}$ & $\begin{array}{l}\text { Not effective, because it could be fixed } \\
\text { assets that have been utilized the value that } \\
\text { will be exhausted, and let alone fixed assets } \\
\text { in the construction company project }\end{array}$ \\
\hline \multirow{2}{*}{\multicolumn{3}{|c|}{$\begin{array}{l}\text { Source: Processed Data in } 2017 \\
\text { Information } \boldsymbol{\&} \text { Communication }\end{array}$}} \\
\hline & & \\
\hline $\begin{array}{l}\text { Theory } \\
\end{array}$ & $\begin{array}{c}\text { Application in PT Lumbung Berkat } \\
\text { Indonesia }\end{array}$ & Analysis Result \\
\hline Depreciation Method & $\begin{array}{l}\text { Depreciation method using straight-line } \\
\text { method in accordance with PSAK and } \\
\text { done consistently }\end{array}$ & $\begin{array}{l}\text { It is good, implemented according to } \\
\text { standardization and carried out continuously } \\
\text { and consistently }\end{array}$ \\
\hline List of Fixed Assets & The list of fixed assets is not up to date & $\begin{array}{l}\text { Not effective, because the company's fixed } \\
\text { assets must provide accurate information on } \\
\text { the existence of these assets. }\end{array}$ \\
\hline
\end{tabular}




\begin{tabular}{|c|c|c|}
\hline \multicolumn{3}{|c|}{ Monitoring Control } \\
\hline Theory & $\begin{array}{c}\text { Application in PT Lumbung Berkat } \\
\text { Indonesia }\end{array}$ & Analysis Result \\
\hline Monitoring Process & $\begin{array}{l}\text { The process of supervising fixed assets } \\
\text { is not yet organized }\end{array}$ & $\begin{array}{l}\text { Not effective, because it will impact on the } \\
\text { effectiveness and efficiency as well as the } \\
\text { quality of the company's operational } \\
\text { activities. }\end{array}$ \\
\hline
\end{tabular}

Source: Processed Data in 2017

\section{CONCLUSION}

From the results of research conducted by the author, it can be concluded that the internal control of fixed assets conducted PT Lumbung Berkat Indonesia has not effectively run as standardization. It can be seen from the corporate control environment that it does not have company philosophy, in the control environment associated with the organizational structure of the company there is no separation of duties and responsibilities between the finance and accounting, the absence of audit committees that will result in less efficient supervision of corporate activities, especially for fixed asset policy. Also, they do not provide adequate training time more than three months.

Risk assessment in PT Lumbung Berkat Indonesia has not been effective because the company's management has never conducted testing and measurement of fixed assets. The company should also separate the expenditure between capital and revenue expenditures for fixed assets in accordance with PSAK No. 16 which will affect the company's financial statements. Control activities conducted by PT Lumbung Berkat Indonesia in the case of authorization has been running well, because all fixed asset transactions conducted based on authorization of the President Director. However, for physical control over fixed assets, the company has never conducted physical fixed assets matching with fixed asset records.

For information on fixed asset depreciation method, the company has already used the straight-line depreciation method and executed continuously. However, the list of fixed assets of the company has not been up to date, since the company only attaches fixed assets in the form of buildings and vehicles in the project (excluding vehicles and inventory in the office). In terms of supervision of fixed assets conducted by PT Lumbung Berkat Indonesia it has not been effective due to lack of adequate control of the financial and accounting divisions. We have seen on the field that taxation and HRD in charge on the preparation of the list of depreciation of fixed assets of the company. Physical fixed asset matching with the list of fixed asset has never been done.

Based on the results of the discussion and by looking at the condition of the company, the author suggest several things that must be improved as follows;

1. It needs to be a separation of role and responsibility functions between the accounting and finance sections. It is necessary to enforce the role of the Audit Committee to exercise oversight of the company's operational activities.

2. Increase training time minimum of three months.

3. The company needs to conduct testing and measurement of fixed assets.

4. The company should make a separation of capital and income expenditures.

5. The company must report all the fixed assets on the list of fixed assets of the company.

6. The company must conduct physical matching of fixed assets with a list of fixed assets to ensure that the amount and value of the fixed assets to be reported is correct. 


\section{REFERENCES}

Andreas Indra Cahyadi. 2013. Analisis Pengujian Pengendalian Aktiva Tetap dalam Mendeteksi Kehilangan Aktiva Tetap pada Stikes Perdhaki Charitas Palembang. Jurnal STMIK GI MDP

Cahyadi, Indra Andreas.2011. Analisis Pengujian Pengendalian Aset Tetap pada STIKES Perdhaki Charitas Palembang. Skripsi Palembang.

Erwin Budiman. 2016. Analisis Pengendalian Intern Aset Tetap pada PT. Hasjrat Multifinance Cabang Manado. Jurnal Hasil Reset Profesi Akuntansi Unsrat

Giri Efraim Ferdinan. 2012. Akuntansi Menengah 1. Jogjakarta: UPP STIM YKPN

Halim, Abdul. 2012. Auditing. Dasar-Dasar Audit Laporan Keuangan, UPP STIM YKPN, Yogyakarta.

Hery. 2014. Akuntansi Aset, Liabilitas, dan Ekuitas.Penerbit PT. Gramedia Widiasarana Indonesia. Jakarta.

Karyono. 2013. Forensic Fraud. Penerbit CV Andi Offset. Yogyakarta

La Midjan dan Azhar Susanto. 2014. SIA Pendekatan Manual Penyusunan Metode-Metode Prosedur Edisi 8. Lingga Jaya

Mulyadi.2013. Sistem Akuntansi. Salemba Empat, Edisi 3. Yogyakarta.

Pradana, Yoga\&TubanDrijahHerawati (2015),Penerapan PSAK No. 16 tentangAsetTetap $\begin{array}{lllll}\text { pada } & \text { PTPerkebunan } & \text { Nusantara } & \text { XI } & \text { (Persero) }\end{array}$ SoedhonoNgawi.JurnalImiahMahasiswa FEB UniversitasBrawijaya Malang.Volume $3 \quad$ No 1.http://jimfeb.ub.ac.id/index.php/jimfeb/search/authors/view?firstName=Yoga\&midd leName $=\&$ lastName $=$ Pradana\&affiliation $=\&$ country $=$ ID.Diakses $25 \quad$ Januari 2016

Santosa, Muhammad Syahmi. 2012. Peranan Sistem Pengendalian Intern Aktiva Tetap Terhadap Pengelolaan Aset Tetap Perusahaan Daerah Air Minum (PDAM) Pekalongan. Jurnal Universitas Dianuswantoro Semarang

Sunyoto Danang, S.H, S.E, M.M. 2014. Auditing Pemeriksaan Akuntansi.Jilid I. Penerbit Center of Academic Publishing Service. Yogyakarta.

Surya, Raja AdriSatriawan (2012),AkuntansiKeuangan IFRS.Edisi Pertama.PenerbitGrahallmu.Yogyakarta.

Suwardjono. 2013. Akuntansi Pengantar. Edisi Keenam. Penerbit BPFE.Yogyakarta.

T Trimaryadi. 2007. Peranan Pemeriksaan Internal Terhadap Efektivitas Pengendalian Intern Aktiva Tetap pada Perusahaan Daerah Air Minum (PDAM) Kota Bandung (studi kasus pada PDAM Kota Bandung). Jurnal Widyatama. 2540 